\title{
The Implementing of Adat Badamai Value in Strengthening National Commitment in Banjarmasin People
}

\author{
Mariatul Kiptiah \\ Universitas Lambung Mangkurat \\ Banjarmasin, Indonesia \\ mariatulkiptiah@ulm.ac.id
}

\author{
Bunyamin Maftuh, Elly Malihah, Iim Siti Masyitoh \\ Universitas Pendidikan Indonesia \\ Bandung, Indonesia
}

\begin{abstract}
Banjarmasin people has a local wisdom that serves traditionally in solving social conflicts, known as Adat Badamai. Adat Badamai is one of dispute resolution way that is customarily done by Banjar society. It is defined as a result of the deliberation process in purpose of attaining the decision as a problem-solving. This research is aimed at obtaining a description of implementing of Badamai Customary values as to strengthen national commitment. This research employed a qualitative approach and a case study method. The informants were chosen purposively from various groups based on their expertise. The results of this study found the nationalism commitment or the attitude of nationalism is embedded in the Adat Badamai of the Banjarmasin people. It covers the attitudes of the love of diversity and kinship and the love of customary/cultural values as well as the love of harmonious and peaceful life.
\end{abstract}

\section{Keywords - adat badamai value; national commitment}

\section{INTRODUCTION}

Sense of nationhood has always been binding together that are visible in the attitude of one unit. The unity fosters a sense of feeling "unite" in a certain nationality concept. It can be said that the patriotism (love of motherland) which is a moral and political principle which contains loving towards the homeland, emotional pride towards the history and self availability to defend the interests of nations.

Sense of nationhood might be appreciated as a sense of solidarity or friendship of citizenships social life gathered in a nation-state. Friendship or social solidarity includes solidarity inside the society in order to address the various challenges and obstacles for the sake of ambitions realization.

The national commitment shown by the community is a form of commitment awareness of the responsibility attitude, and sense of having interest togethers to improve the Banjarmasin development, so that people seems to be summoned to support all policies related to the societies' interests.

Their national commitment is reflected in the attitude of Banjarmasin people in terms of a sense of belonging to the homeland where they were born and raised. Then the senses are continually growing time to time in various forms, so sense of nationhood in Indonesia is like something that continues to raise and move dynamically with the society development from time to time. The definition of sense of nationhood is not static but it tends to be dynamic following the development of society. "Dimensions of Conflict Resolution in Ethnopolitical Disput" Conclusion this article is agreed to the command of peace, at least there are two things that must be considered viz: (1) at least develop relation cooperation of parties involved, and (2) at least agree upon an agreement that made to create harmonization [1].

Banjarmasin people still prioritize local values in solving the problem, for instance through Adat Badamai, which is one of the forms of dispute settlement that is commonly done by the Banjar community. Adat Badamai is also defined as a result of the process of conspiracy or deliberation by the aim of reaching decision in solving problems. Adat Badamai has been done in order to avoid disputes that may endanger the social order. Badamai`s verdict generated through "musyawarah". It is an attempt to find alternative solution in solving the problems occured in society. In Banjar community, if there are cases likely disputes among citizens, acts of torture, violation of norms, fight, or traffic violations; they will solve it in Badamai. They are reluctant to resolve it through litigation agencies.

The Banjar societies` understanding of Adat Badamai values is considered important as a cultural part that from time to time has ups and tidals. In particular, when dealing with change and modernization. Adat Badamai describes the easter culture which is familiar with the values or views of society characterized by mechanical solidarity, in these conditions customary functional badamai and very appropriate as a solute mechanism in solving various problems in the community.

Notion of nationality is included a historical aspect, the soul of a spiritual principle arising from the past glory; and solidarity aspect, desire to live together in present. They are formed and built in remaining the past inherited, either for current or for future time [2].

As seen by the context of Banjar societies understanding towards Adat Badamai, sense of nationhood not only can be arisen differently by person to person with their invidual insticts, but also can be arisen in groups with potentially tremendous powers. The dynamic of nationhood sense in 
achieving the ideals of the nation develops into nationalyties point of view. In example, national though in which a nation has a common ideal of life and nation goal. It its dynamic, the national outlook of a nation to other nations is interacting and effecting each other. By cultural clashes and metamorphosis in a mixture of cultures and syntheses, the degree of nationality of a nation becomes dynamic and grows strong and crystalized in nationalism. So in this case, it needs implementation of Adat Badamai in strengthen in national commitment of Banjarmasin society.

\section{RESEARCH METHODS}

The research conducted is qualitative, so that the data are collected and analyzed is descriptive, narrative, argumentative through exposure sentences. Of the reasons to select research methodology this qualitative because the data collected contains view deep people banjar on the implementation of value customary badamai that cannot be achieved through size the calculation of figures. The use of this qualitative research methods influence the choice of determining the location of the study, the determination of the informant, type and source data as well as data collection and analysis techniques studied.

\section{DISCUSSION}

The national insight also establishes the way a nation utilizes the country`s geographical, socio-cultural, economical and political conditionss as well as the defense of security in achieving its goals and ensuring the national interest. The insight of nationality determines the way in which the nation places itself in relationships with other people and in association with other nations in the international world. The values of national insight are respect for prestige and dignity as creatures of Almighty God, a common determination to live freely and unity, love of the homeland and nation, democracy and popular sovereignty, social solidarity, just and prosperous society.

Life teaches us that human memory is not so easy to be underestimated. When we take a look at history we see a various of forms of recording that help us to reinterpret the significance of the Indonesian people's struggle to be free from the colonists at that time. In Indonesia, in context of nationalism, civil society became the focus of the discussion in Kompas daily to commemorate 100 years of national awakening in 2008.

For everyone it must have a sense of nationality and have an insight into the nationality of feelings or thoughts even in his conscience. In reality, the sense of nationalism is llike something that can be felt but difficult to be understood, but may appear in the form of thought when the sense of nationality is touched. It is a consciousness born naturally because of the social togetherness that grows from the culture, history and aspirations of the strglle in the past, even togetherness in facing the challenges of history at this time. The dynamism of this sense of nationalism in achieving the ideals of nations developed into an insight of nationality, which is the nationalistic that a nation has a clear ideals of life and national purpose. Thus, based on a sense of nationalism that will emerge the spirit of nationalism or patriotism spirit.
In relation to the concept of nationality above, nationalism is also a social movement or spiritual flor that unites the people into states that evoke time into active political and social conditions. With the spirit of nationality as a manifestation of national consciousness that contains the ideals that give birth to inspirations which encourages and stimulates a nation. As Isjwara mentioned four types of national ideals or nationalism [3]:

- Effort to realize unity of nations, including political, economical, social, religional, cultural, and federation and solidarity field.

- Effort to realize the national freedom, including freedom of internal forces which are neither national nor the willingness to take aside the nation or state.

- Effort to realize the solitude, diversity, individualist, fidelity and privilege.

- Effort to realize the distinction among nations which includes effort to take the loyalty, dignity, prestige and influence.

The national attitude shown by the community is a form of commitment to responsibility awareness and sense of shared aspirations to improve the development in Banjarmasin so that people also feel called to support all policies related to the interests of the community.

Related to the objective of the educational law, the term of nationalism commitment consists of two syllables, namely insight and nationality. Etymologically, the term insight is defined as the result of observing, review and also the conception of Indonesian dictionary, 1989). The commitment of nationality can also be interpreted as a point of view that has person's ability or group of people ability to understand the existence of his identity as a nation in viewing themselves and behave according to the philosophy of life of the nation in the internal environment and the national commitment also determines a nation to utilize the countries' geoghrapic, historical, socio-cultural, economical and political conditions as well as the defense of security in achieving its goals and ensuring the national interest.

Commitment of nationalism determines the way the nations puts itself in the relationship with fellow nation and in interaction with other nations in the international world. The values of national commitment are the appreciation of dignity as the creature of the Almighty God, the common determination for a free, independent and united life, the love of the homeland and the nation, the democracy and the sovereignity of the people of solidarity, social and prosperous society.

Apart from all the deficiencies in its implementation, the sense of nationhood and democracy of Indonesia in realizing the ideals of the Fathers of nations is to realize a prosperous, sociey prosperous in Indonesia diversity still needed. As proposed by sociologist durhkeim who argues that nationalism can be new religion in modern society, being able to become integrators of plural societies when social relations are becoming more loose and very materialist [4]. 
From those ideals of nationality by looking at the result findings, it is clear that the appearance of identity of Banjar society seems to be felt as a group of citizen who are willing:

- Banjar societies have the same ambitions tied up themselves as citizenship to be united with Indonesia.

- Banjar societies have similar customs, cultures, and behaviors as the impact of historical experience for living together.

- Banjar societies have dark historical life in their inherited homeland so they are bound in a legal of society.

- Banjar societies places in particular area which is a united area.

- Banjar societies are organized within one state government so that they have been tied up into legalicy societies.

Based on the appearance of Banjar people regarding their understanding of their nationality, it is known that the sense of nationality is one form of homeland loving which then created a sense of togetherness for its belonger. By the most common goal, they form a goal in building areas where they were born and raised.

The reflection of Banjar societies commitment is expressed in third article of Pancasila, which is the Indonesian Unity as the basis of ideology of the Pancasila should be the reference of our framework in building a national life. Due to other ideological basis of the state, Pancasila which has been established as a source of law by the People consultative assembly is always seen as a cultural paradigm in implementing the slogan of Bhinneka Tunggal Ika. That socalled nation in the context of nationalism is a concept addressed to the community as a unity of collective life, which includes various elements of the ethnic, social class or social aspect, cultural belief system and language and so forth. All of them are integrated into historical development as a unity of political system based on solidary supported by common political [5].

Furthermore, Indonesia nationalism raises Pancasila as the state of ideology. The long and hard effort to achieve Independence are made true. The proclamation of Independence, 17th August 1945, is the culmination of all struggles and at the same time is a sign Indonesian people declared as sovereign and independent. Right after that day, on 18th August, there became a symbol of a great revolutionary power including equality and fraternity [6]. By legalicing the 1945 constitution, the Proclamation spirit is then called as the foundation of the philosophy of the Indonesian Republic and obtaining its form and legalicy basis.

It is therefore important that every citize should have an understanding ofthe national commitment, thus citizens have the awareness to continue maintaining and re-sharpening the values of nationality. In brief, a good nationalism commitment tends to buid a sense of Indonesian nationalism which is attachment and interrrelation between the parts of Indonesian nation occured dynamically to create a harmonious life of the earth, Lambung mangkurat, and obtain prosperity and happiness.

Based on the analysis, Banjar national community commitment assume that : First, Banjar society is assuming themselves as an integral part of Indonesia democratic political system; Second, the Banjar society is triggered themselves as part of the national history and is part of system political democracy of the nation; Third, Banjar society is fully aware that sense of nationhood is a manifestation of sense of common destiny and togetherness to face challenges and threats in order to unite the determination to be a powerful nation and respectful by other nations.

The research data revealed the big picture of Banjar society commitment is quite good. The description of the result revealed some attitudes shown by Banjar society, whether it is the love feeling toward the homeland, proudly feeling as Indonesian, supported feeling to local goverment despite the negative feeling of disappoinment toward the government performance. The disappoinment will not change nationality commitment of Banjar people over their social life, nation and state.

It seems to the Banjar Society that knowledge of their national commitment is reflected in their attitudes or sense of belonging, as the national attitude is manifested through democratic political system that is closely related to somebody`s emotional life concerning their feeling as Banjar people, Indonesian, to object of attitudes related to emotional matters. Attitude is a response issued by a person to what is happening in this case the attitude of Banjar society towards the commitment of nationality through their attitude in the current democractic, political system. It is in reference to Branson that the purpose of civic education epistimologically is a qualified and responsible participation in politic and community life either in local, state or national levels [7]

The national commitment shown by the Banjar society is a form of commitment towards the awareness of responsibility manner and similar ambitions to enhance development in South Kalimantan, so Banjar society is triggered to support any kind of policies related to society interests.

Based on the nationality appearance shown by Banjar society, their national commitment is reflected inside their emotional. It means they have sense of loving their homeland where they were born and grew up. The sense is continually raising time to time in various shapes. Sense of nationhood in Indonesia is depicted by something that continually live and dynamically moves as well as the society development in time. That analogy illustrates that nationalism is not statical yet quite dynamically following the society`s development.

Shafer pointed out that nationalism is multi-meanings, it depends on the objective and subjective circumstance of each nations. Shafer defines nationalism into five sense, they are [8]:

- Nationalism is a love of similar homeland, race, language or culture. In other word, it is similar to patriotism

- Nationalism is a desire for freedom of political salvation and prestige of nation 
- Nationalism is a mystical service to a vague, sometimes even supernatural, social organism called a nation or Volk that is more prominent than its part

- Nationalism is a dogma that teaches individuals to live only for the nation

- Nationalism is a doctrine stating that its nation has to be the most dominant or the highes parts among the other nations. Further, it has to act agressively.

Commitment of nationality always binds involving people into a unit of emotional. The unit of emotional builds a sense of "unity" in concept of particular nations. Briefly, it can be said that patriotism is a moral and political principal containing love toward homeland, emotional proud to history and selfavailability to defend the interest of nations.

The national commitment is shown by solidarity and social solidarity of citizens life gathered in nation-state. Social solidarity includes solidarity of society in aiming at dealing with any barriers and obstacles for the sake of group interests realization

Banjar people are fully aware that the concept of nationalism is fundamental to them as part of Indonesian nation. That in reality, the concept of nationality has become the basis of state and national ideology. It has been formulated in Pancasila as contained in Line IV Preamble of UUD 1945. The concept of nationalism diverses Indonesian nation to other nations.

The illustration of national spirit and patriotism depict that national attitude of Banjar society discussed more opinions about Pancasila, one of them is principle statement about Pancasila as a guidance of life to determine their national attitude. The principle is based on observation of the southern Borneo history from colonial period. It trends to bring suffering to the community. It is in line with Renan in Notonagoro suggestion that nationalism in context of Pancasila is "Bhineka Tunggal Ika" [9]. Further, He mentioned some kinds of component forming nationalism of Indonesia, they are as following:

- It has been long time, since the kingdom of sriwijaya, kingdom of majapahit, several Islamic empires, colonialism and VOC. Nationalism was coined by several youth generations in youth declaration on 28th October 1945. Nationalism had been on summit when the Indonesia was taking the independece against Japan, on 17 August 1945.

- The unity of fate, nation of Indonesia is built for the sake of similar fate, that is suffering during the colonial period and effort to seize independence separately and together, so that Indonesia got blessing for their nation and got opportunity to proclaim Independence ahead of the Japanese occupation.

- The unity of culture, in spite of Indonesia nation has various cultures and adheres to different beliefs, yet overall there is a culture allied and linked to the bulk of religious part believed by Indonesian, such as Hindu and Islam.
- The unity of territory, Indonesia nation lives and earns for living in the similar region. It is Indonesia.

- Spiritual unity of the principle, Indonesia nation has the similar interests, philosophy point of view derived from their life point of view toward Indonesia country and society in back and forth.

Further, a path to seize Indonesia nation is not as easy as thought, since Indonesia people should have not to forget group of intellectual. Kartodirjo stated that as a result of teaching development in Indonesia, new social groups with new functions and status referring to stereotype in the field of socioeconomic and government also builds to a group of professional who not to have place on strata. This is the professional group whose social position allows them to be protagonists of modernizationin general and as the pioneers if nationalism in particular [5]. As the first generation who demanded as western system lessons, they not only absorbed knowledge from the various of knowledge fields, but also formal education experince that established new attitudes that include social disciplinek, rational lifestyle thinking according to time scbedules and other values.

"A Model of Conflict Resolution in Public Participation GIS for Land-Use Planning", This article explains how to improve public participation in decision making on the model of GIS trackers, in an effort to conflict resolution. In this model, conflicts are designed to solved through two levels of all the special level. Value up, the process of building consensus is done to help them that understood and reach an agreement. At the level of special, those who are involved in it is requested to open the discussion on the major issues to debate [10].

Demonstrated that integration will not be realized if discrimination as an entrenched problem in this republic. However, the discrimination is not emerged as a cultural problem of society, but emerged as result of statical policy [11]. The result contains elements of everything from the era of Dutch East Hindis colonialism, the destroying of "Orde Baru" regime. Due to long-standing state policies, prejudices and stereotypes are deeply rooted inside ourselves. In reference to Setiawan, a post-reformation is integrated to pluralism, a unified diversity based on self-respect [11]. By this concept, integration can alluviate the diversity but it can be strengthening the awareness to maintain the balance among of them.

"Reiterating National Identities (The European Union Conception of Conflict Resolution in Northern Ireland), Cooperation and Conflict" The core of this article is articulation without violence based on the process to achieve peace is a dynamic implication the success of conflict resolution. National and international life situations a harmonious will create peace force to have been made to inherit the next generation. That is why it is national identity should be strengthened so as to have the same even though with an approach that varying in conflict in resolution [12].

Syarif argued that challenges to strengthen national commitment to border communities due to education and infrastructure development problems that lack the 
government's attention, the utilization of natural sources are not fully for the people prosperity. Challenges arise from outside, they are influence of intercultural communication, entrance of other cultures and import products. There are several ways to improve national charact of Entikong community, namely improving the quality of education, building facilities and infrastructure, promoting economic sectors, conducting activities involving communities, preserving customs and local wisdoms and commemorating national holidays

\section{CONCLUSION}

Adat Badamai is a deliberative effort to reconcile the parties to conflict and dispute. Adat Badamai is a conflict resolution for Banjar people in order to resolve, prevent and resolve disputes and conflicts occured to Banjar societies.

Nationality commitment or attitude of nationalism has been reflected through the existence of Adat Badamai within Banjarmasin societies. Among the attitudes of nationalism is the attitude of diversity loving and kinship, the values of custom or culture loving and life in peace and harmony loving.

\section{REFERENCES}

[1] F.S. Pearson, "Dimensions of Conflict Resolution in Ethnopolitical Disputes," Journal of Peace Research, vol. 38, no. 3, pp. 275-287, 2001.

[2] E. Renan, Apakah Bangsa itu (Qu'est ce qu'une nation). Jakarta, Erlangga, 1965.

[3] F. Isjwara, Pengantar Ilmu Politik, Bandung: Bina Cipta, 1992.

[4] Kompas, 3 April 1996

[5] S. Kartodirdjo, Negara dan Nasionalisme Indonesia, Jakarta. Grasindo, 1995.

[6] G.M.T. Kahin, Nasionalisme dam Revolusi di Indonesia, Solo: Pustaka sinar Harapan dan Sebelas Maret University Press, 1995.

[7] M.S. Branson, Globalization and Its Implications for Civic Education, 1999

[8] B.C. Shafer, Nationalism: myth and reality, Harcourt, Brace, 1955.

[9] Notonagoro, Kuliah Teori Pendidikan Nasional Pancasila, FIP IKIP Yogyakarta, 1973

[10] Z. Yongjun and F. Tung, "A model of Conflict Resolution in Public Participation GIS for Land-Use Planning," Environment and Planning B: Planning and Design, vol. 40, no. 10, pp. 550-568, 2013.

[11] D. Setiawan, "Integrasi dalam Proses Pembentukan Identitas Bangsa untuk Menumbuhkan Budaya Kewarganegaraan (Kajian terhadap Tokoh Etnis Tionghoa di Kota Medan)," Disertasi Doktor Pada Prodi Pendidikan IPS UPI Bandung, tidak ditertibkan, 2011.

[12] H. Katy, "Reiterating National Identities (The European Union Conception of Conflict Resolution in Northern Ireland)," Cooperation and Conflict: Journal of the Nordic Internasional Studies Association, vol. 41, no. 3 , pp. 261-284, 2006.

[13] F. Syarif, "Tantangan Penguatan Komitmen Kebangsaan untuk Membangun Karakter Warga Negara pada Masyarakat Entikong," Jurnal Civicus, vol. 18, no.1, pp. 65-79, 2014. 